Acta Universitatis Wratislaviensis No 3998

Anglica Wratislaviensia LVIII, Wrocław 2020

https://doi.org/10.19195/0301-7966.58.8

\author{
Wojciech Witkowski \\ ORCID: 0000-0001-8873-9819 \\ University of Wrocław \\ wojciech.witkowski@uwr.edu.pl \\ Bożena Rozwadowska \\ ORCID: 0000-0001-9029-6463 \\ University of Wrocław \\ bozena.rozwadowska@uwr.edu.pl
}

\title{
(Non-)Intentional Readings of Labile Object Experiencer Psych-Verbs in Polish: Insights from a Self-Paced Reading Study
}

\begin{abstract}
Labile Object Experiencer psych-verbs are well-known to be compatible with intentional and non-intentional readings. When used in intentional contexts, labile OE psych-verbs exhibit properties of canonical agentive verbs. Previous studies on the agentive nature of labile OE psych-verbs indicate that it varies cross-linguistically. This article aims at investigating the properties of Polish labile OE psych-verbs in terms of their usage in non-intentional and intentional contexts, and in contrast to canonical agentive verbs. The results of the self-paced reading experiment showed that (i) processing of Polish labile OE psych-verbs in non-intentional and intentional contexts, as well as (ii) processing of labile OE psych-verbs as compared to canonical agentive verbs result in significantly faster reading times. The differences were, however, observed in different clause regions and therefore are argued to result from two distinct underlying causes.
\end{abstract}

Keywords: object experiencer, psych-verbs, self-paced reading, agentivity

\section{Introduction}

Psych predicates include Subject Experiencer (SE) verbs (Italian temere 'to fear' class), Object Experiencer (OE) verbs (Italian preoccupare 'to worry' class), and Dative Experiencer (DE) verbs (Italian piacere 'to please' class). Cross-linguistically, SE verbs are taken to be stative transitive verbs. DE verbs are also taken to be stative, but with an unaccusative structure (Pesetsky 1995; Landau 2010). The 
most widely-studied and the most controversial subclass of psych verbs have been OE verbs, which are ambiguous between three interpretations: stative, eventive, and agentive. Stative reading is contrasted with eventive and agentive readings; however, the aspectual distinction between the latter two is often unclear and reduces to the contrast between animate and inanimate subjects.

Agentive readings arise when the instigator of the action is understood as volitional, (see (1)), the adverb is used to highlight the deliberate character of the action and the action triggers a change of state in the EXPERIENCER. With respect to the aspectual classification, the agentive readings are treated as accomplishments composed of a process that leads to a change of state (see Grimshaw 1990; Pesetsky 1995; or Landau 2009).

(1) John has intentionally irritated Mary.

agent --------------> mental state (indefinite)

Arad (1998) and Alexiadou, Iordachioaia (2014) define eventive reading as one that involves an animate or an inanimate CAUSE which triggers a change of state in the EXPERIENCER. The new (mental) state triggered by the CAUSE lasts independently of further perception/action of the CAUSE, as illustrated in (2).

(2) The news irritated Mary in five minutes.

cause ---------------> mental state (indefinite)

According to Arad, stative reading arises in clauses with the OBJECT-OFEMOTION perceived continuously for a prolonged time. The perception of the OBJECT-OF-EMOTION by the EXPERIENCER is involuntary. Stative readings are illustrated in (3) and (4).

(3) Dogs frighten Mary.

(4) Mary fears dogs.

Perception of a stimulus: Mental state: stop stop

Polish psychological verbs are not an exception with respect to this behaviour. As shown in (5)-(9), they can readily be found in agentive, eventive, and stative readings. The eventive reading correlates with the perfective aspect in (5)-(7), whereas the stative reading with the imperfective aspect in (8) and (9).

(5) Jan celowo wystraszył $\mathrm{pfv}^{\mathrm{fv}}$ Marię.

Agentive

'John has intentionally scared Mary.'

(6) Ta wiadomość zirytowała ${ }^{\text {pfv }}$ Marię.

Eventive

'This news irritated Mary.'

(7) Maria zdenerwowała ${ }^{\text {pfv }}$ się wynikami egzaminu.

Eventive

'Mary became angry about the results of the exam.' 
(8) Psy przerażają ${ }^{i p f v}$ Marię.

Stative

'Dogs frighten Mary.'

(9) Maria boi ipfv się psów.

Stative

'Mary is scared of dogs.'

Although the previous research on OE psych-verbs (Arad 1998; Landau 2010) has shown that on their agentive readings OE psych-verbs behave like canonical agentive verbs, and do not exhibit any of the so-called psych-properties such as e.g. passivization restrictions, experiencer object preposing, or extraction restrictions. More recently, the agentive and eventive characteristics of labile OE psych-verbs, i.e. OE psych-verbs which can be understood either agentively or eventively, have been also analyzed from a psycholinguistic perspective. The next section reviews the case studies relevant for the discussion of the agentive and eventive properties of Polish psych verbs.

\section{Agentivity and eventivity of OE psych-verbs}

In this section we review previous research focused on labile OE psych-verbs in their agentive (intentional) and eventive (non-intentional) readings. The results of these experiments will serve as the starting point for the discussion of the behaviour of Polish labile OE psych-verbs in the two readings.

\subsection{Verhoeven (2010): Cross linguistic study of OE verbs' agentivity}

Verhoeven's (2010) study aims at determining the empirical adequacy of the internal division of $\mathrm{OE}$ psych-verbs into agentive and eventive readings. In order to analyze the effects of agentivity, Verhoeven postulates the division of OE verbs into two groups: (i) labile agentive $\mathrm{OE}$ psych-verbs and (ii) non-agentive OE psych-verbs.

Labile OE psych-verbs have the following properties: (i) STIMULUS argument is realized as an NP referring to an animate entity, which may be understood as exercising sentient control over the event denoted by the verb and (ii) EXPERIENCER argument NP is marked with the structural accusative case. Following Van Valin and Wilkins (1996), Verhoeven assumes that if the STIMULUS argument refers to an animate entity (especially to a human) and can be understood as the CAUSE, the verb can be interpreted as agentive. This interpretation arises due to pragmatic inference by which human stimulus is understood as an AGENT when there is no information that would rule out this inference.

In contrast, non-agentive OE psych-verbs are either (i) OE psych-verbs whose STIMULUS argument is realized by an NP referring to an inanimate entity and EXPERIENCER argument NP is marked with the structural accusative case or (ii) OE psych-verbs whose EXPERIENCER is marked with an inherent case, e.g. Dative experiencer verbs (intransitive OE verbs in Verhoeven's terminology). 
Based on the above division of OE psych-verbs, Verhoeven conducted an acceptability judgement study in German, Modern Greek, Chinese, Turkish, and Yucatec Maya in which respondents were asked to rate the felicity of the clauses on a scale from 1 (not acceptable) to 7 (completely acceptable). The experiment data were divided according to the following criteria:

1. Context type: volitional context ${ }^{1}$ — elicited by the presence of the volitional adverb, e.g. intentionally, on purpose, in the clause; imperative context, non-stative context-elicited by enforcing dynamic interpretation of the event denoted by the verb

2. OE verb class:

- conditions: labile agentive OE verbs; non-agentive (stative) OE verbs, intransitive (Dative) OE verbs

- control groups: canonical agentive verbs; stative transitive SE verbs

The results of this experiment have revealed that in languages such as German and Modern Greek (i) labile OE psych-verbs do not differ from canonical agentive verbs and (ii) non-agentive OE psych-verbs, intransitive (dative) OE psych-verbs, and transitive stative SE psych-verbs do not differ significantly with respect to each other in terms of their acceptability. However, the individual types of the verbs were shown to significantly differ between groups. Canonical agentive verbs and labile agentive $\mathrm{OE}$ psych-verbs are rated significantly higher than non-agentive $\mathrm{OE}$ verbs, transitive SE verbs and intransitive (dative) OE psych-verbs. With respect to Turkish and Yucatec Maya, labile OE psych-verbs, non-agentive OE psych-verbs and canonical agentive verbs do not exhibit significant differences with respect to each other.

Verhoeven (2010) interprets these results as indicating that labile agentive OE psych-verbs pattern like canonical agentive verbs, i.e. the acceptability of labile OE psych-verbs in agentive contexts is not different from the acceptability of canonical agentive verbs. Therefore, labile $\mathrm{OE}$ psych-verbs in agentive contexts can be treated as regular agentive verbs.

2.2. Grafmiller (2013): OE verbs constitute a uniform group with respect to agentivity

Following Verhoeven's (2010) analysis, Grafmiller (2013) carried out a comparable study of the compatibility of OE psych-verbs with agentive interpretations of the non-EXPERIENCER argument with a human referent in English. Parallel to Verhoeven's experiment, Grafmiller's acceptability judgment test consisted of four groups of verbs:

1 Verhoeven (see also Sonnenhauser 2010) notes that the compatibility of the verb with the intentional adverb cannot be treated as a straightforward indication of agentivity. Felicity of clauses with $\mathrm{OE}$ verbs and intentional adverbs has to be interpreted only as an indication of the support for occurring in agentive readings. 
- canonical agentive verbs, e.g., help, hang, kick,

- agentive (labile) OE verbs, e.g., amuse, anger, annoy,

- non-agentive (stative) OE verbs, e.g., amaze, astonish, depress,

- SE verbs, e.g., admire, adore, despise;

which were presented across four contexts:

- clauses with adverbs of intent, e.g. intentionally,

- clauses in which the tested verbs were complements of control verbs,

- imperative clauses,

- progressive clauses.

Respondents (experiment participants) were asked to judge the naturalness of each clause on a scale from 1 (completely unnatural) to 7 (perfectly natural). The assignment of the OE psych-verbs to agentive and non-agentive groups was made on the basis of the degree to which respective verbs conformed to agentive diagnostic tests that correspond to the four experimental contexts. As expected, the results of this experiment showed that agentive $\mathrm{OE}$ psych-verbs are rated higher than non-agentive $\mathrm{OE}$ psych-verbs in agentive-reading inducing contexts. The average difference in rating is statistically significant and equals 0.92 . This, in turn, suggests that $\mathrm{OE}$ psych-verbs can be divided into two distinct classes: (i) agentive and (ii) non-agentive.

However, as noted by Grafmiller (2013), the above conclusion would be premature since the tested verbs were assigned to agentive and non-agentive classes as a part of the experiment design, i.e. their assignment to respective class was not an outcome of the experiment, but was one of the assumptions on the basis of which the experiment was conducted. Therefore, in order to cross-validate the results suggesting a division of $\mathrm{OE}$ psych-verbs into agentive and non-agentive classes, Grafmiller compared the ratings for individual verbs. This has shown that the differences between individual verbs are not as striking as would be expected if the division of OE psych-verbs into two classes would properly describe the semantic characteristics of these verbs. The ratings for the verbs in the two experimental groups of OE psych-verbs overlap to a degree that does not support the dichotomous division and points towards more uniform composition of the OE psych-verb group. Consequently, Grafmiller concludes that OE psych-verbs form a rather homogeneous group with respect to the volitionality of the human referent of the STIMULUS argument, and that no explanatory adequate strict division into non-agentive and agentive $\mathrm{OE}$ psych-verbs should be made.

\subsection{Darby (2016): internal division of OE verbs into more agentive} and less agentive ones

In contrast to Grafmiller (2013), Darby (2016) argues that OE psych-verbs in English form at least two distinct classes with respect to the degree to which they are compatible with agentive interpretation. This approach is based on the results of an 
acceptability judgement study ${ }^{2}$ parallel to that carried out by Grafmiller. However, in contrast to Grafmiller's study, the OE psych-verbs were not a priori assigned to agentive and non-agentive groups. Additionally, the results of the acceptability judgement study served as the input for hierarchical clustering employed to divide the tested $\mathrm{OE}$ psych-verbs into relevant groups.

The ratings for $\mathrm{OE}$ psych-verbs were contrasted with the ratings for canonical agentive verbs and SE psych-verbs. The comparison of the ratings showed that: (i) as expected, canonical agentive verbs are most compatible with agentive readings (these verbs have the highest ratings); (ii) as expected, SE psych-verbs are least compatible with agentive readings (these verbs have the lowest ratings); and (iii) interestingly, OE psych-verbs form two distinct groups as far as their acceptability ratings are concerned.

Verbs such as anger, discourage, annoy, terrify, startle, offend, scare, provoke or embarrass are highly compatible with agentive readings, whereas verbs such as fascinate, concern, interest, depress, worry or please show a significant incompatibility with agentive readings. Yet, their ratings are better than those of SE verbs. Accordingly, Darby (2016) concludes that OE psych-verbs can be argued to exhibit internal division into (at least) two groups distinguished on the basis of their compatibility with agentive readings. As such, Darby's results are in line with Verhoeven's (2010) for German and Modern Greek. Both studies point to the internal division of OE psych-verbs with respect to their acceptability in agentive readings.

\subsection{Interim conclusion}

As shown above, studies focused on the agentive character of psych-verbs point towards a conclusion that $\mathrm{OE}$ psych-verbs can be treated on a par with canonical agentive verbs in terms of their acceptability in volitional readings. However, this behaviour may vary cross-linguistically. Consequently, since Polish was not included in the research summarized above, in this article we present the results of a self-paced reading experiment with a twofold goal. On one hand, we aimed to test if Polish labile OE psych-verbs exhibit differences with respect to their processing in contexts eliciting intentional (agentive) and non-intentional (non-agentive) readings; and if those differences are present which clause region they occur in. Additionally, we focused on the presence / absence of the processing difference between canonical agentive verbs and labile OE psych-verbs in clauses with enforced intentional reading.

2 Darby collected responses from 152 participants who were asked to judge clauses with eventive OE verbs, SE verbs, and canonical agentive verbs co-occurring with adverbs of intent or occurring in a progressive clause on a scale from 1 (completely unacceptable) to 7 (completely acceptable). 


\section{Experiment design}

\subsection{Stimuli}

Stimuli set for this experiment consisted of 54 clauses, arranged into a $2 \times 3$ design in which labile $\mathrm{OE}$ verbs and canonical agentive verbs occurred together with the intentional adverb celowo ('intentionally'), the non-intentional adverb przypadkiem ('accidentally') or the neutral adverb wczoraj ('yesterday'), divided into six separate conditions. Each condition was represented by 18 items, constructed around 9 verbs. Items for each condition were repeated in order to increase the size of the experimental stimuli, which otherwise would be significantly limited by equalling the number of available labile OE psych-verbs. Planned comparisons (see section 2.2.) included only three of the six experimental conditions, the remaining three conditions were used as distractors ${ }^{3}$ (see Table 1). Following Darby (2016), labile OE psych-verbs used in the experiment were not a priori assigned to agentive and non-agentive subgroups. The following verbs were used in the stimuli: ${ }^{4}$

- labile OE psych-verbs: denerwować ('to anger'), dręczyć ('to torment'), kusić ('to tempt'), krzywdzić ('to hurt'), pocieszać ('to comfort'), poniżać ('to humiliate'), straszyć ('to scare'), uspokajać ('to calm'), and uwodzić ('to seduce');

- canonical agentive verbs: drapać ('to scratch'), dusić ('to strangle'), całować ('to kiss'), głaskać ('to caress'), kopać ('to kick'), łaskotać ('to tickle'), przytulać ('to hug'), szturchać ('to poke'), uderzać ('to beat').

To avoid the effects of 'thematic reversal anomalies' (see Kuperberg 2007; Bornkessel-Schlesewsky et al. 2011; Bourguignon et al. 2012) all noun phrases were proper names and had human referents; moreover, all clauses were active. Additionally, to reduce the effects of grammatical aspect differences and morphological complexity (see Klimek-Jankowska et al. 2018), the verbs occurred uniformly in

${ }^{3}$ With respect to creating distractor and filler items in the stimuli set, we followed the definitions of those proposed by Keating and Jegerski (2015). Accordingly, our filler sentences were unrelated to the critical items (items analyzed in planned comparisons), which were constructed around eventive OE psych-verbs and canonical agentive verbs; whereas our distractor sentences shared linguistic properties with critical items, i.e. they were also built around canonical agentive verbs and eventive OE psych-verbs; however, they contained neutral adverbs or a mismatch between the adverb and the verb to counterbalance the adverb-verb combinations in the critical items. Moreover, it has to be acknowledged that no statistically significant differences between mean reading times of critical conditions and distractors were detected.

4 Verbs used in the experimental conditions were controlled for their mean lemma frequency in the National Corpus of Polish (NKJP) (Przepiórkowski et al. 2012). t-test for independent samples did not show significant differences between logarithmic frequencies for the verbs used in planned comparisons:

\begin{tabular}{|l|l|l|}
\hline \multicolumn{1}{|c|}{ Comparison } & \multicolumn{1}{|c|}{ mean log frequency } & \multicolumn{1}{c|}{ t-test } \\
\hline $\begin{array}{l}\text { labile OE psych-verbs vs. } \\
\text { canonical agentive verbs }\end{array}$ & $\begin{array}{l}\text { labile OE verbs }=8.105 \\
\text { canonical agentive verbs }=7.582\end{array}$ & $\mathrm{t}=0.8639, \mathrm{p}$-value $=0.405$ \\
\hline
\end{tabular}


the imperfective aspect. ${ }^{5}$ All stimuli sentences began with an introductory statement of the type Mary said that, whose function was to provide background discourse. This statement was followed by an embedded clause containing the critical adverb and the critical psych- or agentive verb. The embedded clause was followed by a spill-over region in the form of a statement of the type and Mike said so too (see Klimek-Jankowska et al. 2018). Table 1 presents the examples of sentences used in the conditions in Experiment 1, together with the function the condition constituted in the design.

Table 1: Experimental conditions used in the SPR experiment

\begin{tabular}{|c|c|c|c|}
\hline Condition & Stimuli structure & Example & Function \\
\hline Condition 1 & $\begin{array}{l}\text { intentional adverb } \\
+ \text { labile OE verb }\end{array}$ & $\begin{array}{l}\text { Maria powiedziała, że Janek celowo } \\
\text { denerwował Maję, i Maciej też tak } \\
\text { powiedział. } \\
\text { 'Mary said that John was intentionally } \\
\text { irritating May and Mike said so too.' }\end{array}$ & $\begin{array}{l}\text { Experimental } \\
\text { condition used } \\
\text { in planned } \\
\text { contrasts }\end{array}$ \\
\hline Condition 2 & $\begin{array}{l}\text { non-intentional } \\
\text { adverb + labile } \\
\text { OE verb }\end{array}$ & $\begin{array}{l}\text { Maria powiedziała, że Janek przypadkiem } \\
\text { denerwował Maję, i Maciej też tak } \\
\text { powiedział. } \\
\text { 'Mary said that John was accidentally } \\
\text { irritating May and Mike said so too.' }\end{array}$ & $\begin{array}{l}\text { Experimental } \\
\text { condition used } \\
\text { in planned } \\
\text { contrasts }\end{array}$ \\
\hline Condition 3 & $\begin{array}{l}\text { neutral adverb + } \\
\text { OE labile verb }\end{array}$ & $\begin{array}{l}\text { Maria powiedziała, że Janek wczoraj } \\
\text { denerwował Maję, i Maciej też tak } \\
\text { powiedział. } \\
\text { 'Mary said that John was irritating May } \\
\text { yesterday and Mike said so too.' }\end{array}$ & Distractor \\
\hline Condition 4 & $\begin{array}{l}\text { intentional adverb } \\
+ \text { agentive verb }\end{array}$ & $\begin{array}{l}\text { Maria powiedziała, że Janek celowo kopał } \\
\text { Maję, i Maciej też tak powiedział. } \\
\text { 'Mary said that John was intentionally } \\
\text { kicking May and Mike said so too.' }\end{array}$ & $\begin{array}{l}\text { Experimental } \\
\text { condition used } \\
\text { in planned } \\
\text { contrasts }\end{array}$ \\
\hline Condition 5 & $\begin{array}{l}\text { non-intentional } \\
\text { adverb }+ \text { agentive } \\
\text { verb }\end{array}$ & $\begin{array}{l}\text { Maria powiedziała, że Janek przypadkiem } \\
\text { kopał Maję, i Maciej też tak powiedział. } \\
\text { 'Mary said that John was accidentally } \\
\text { kicking May and Mike said so too.' }\end{array}$ & Distractor \\
\hline Condition 6 & $\begin{array}{l}\text { neutral adverb }+ \\
\text { agentive verb }\end{array}$ & $\begin{array}{l}\text { Maria powiedziała, że Janek wczoraj kopał } \\
\text { Maję, i Maciej też tak powiedział. } \\
\text { 'Mary said that John was kicking May } \\
\text { yesterday and Mike said so too.' }\end{array}$ & Distractor \\
\hline
\end{tabular}

5 An anonymous reviewer observes that the adverb przypadkiem collocates more strongly with perfective verbs. Since the perfective aspect is more costly in terms of language processing than the imperfective aspect, we decided not to introduce this additional complexity to avoid possible confusion in our data. The question of aspectual differences with respect to volitional and non-volitional readings of $\mathrm{OE}$ psych verbs requires a separate study and invites future research. 


\subsection{Planned comparisons and predictions}

In order to meet the goals of the presented research (see section 2.4), we focused on the following comparisons. These involve canonical agentive verbs and labile $\mathrm{OE}$ psych-verbs in contexts eliciting intentional and non-intentional readings.

Comparison 1: Following the results of Verhoeven's (2010), and Darby's (2016) studies, in contrast to Grafmiller (2013), we assume that OE psych-verbs exhibit internal division with respect to their compatibility with intentional contexts. However, in contrast to those studies, we focus only on labile OE psych-verbs and assume that these verbs also exhibit processing differences in intentional and non-intentional contexts. Accordingly, we expect to find a statistically significant difference in mean reading times between the clauses eliciting intentional and non-intentional readings.

Comparison 2: Following Verhoeven (2010), Grafmiller (2013) and Darby (2016), we assume that labile OE psych-verbs pattern like canonical agentive verbs in intentional contexts. We expect not to find any statistically significant difference between reading times with respect to clauses built around canonical agentive verbs and labile OE psych-verbs in contexts eliciting intentional readings.

\subsection{Participants and procedure}

54 participants (46 females, 8 males, mean age: 22.7), all native speakers of Polish; students at the Institute of English Studies, University of Wrocław, with no known neurological and reading-related problems) were seated in front of a 22 inch Samsung LCD screen in a sound isolated room. Participants were tested in individual sessions. They were instructed to read the sentences at a natural pace.

Experiment stimuli were divided into 3 versions. There were 6 items per condition in each version. Each participant saw 18 critical sentences used in planned comparisons interspersed with 18 distractor items and 54 filler sentences. In total, the experiment consisted of 90 sentences. Stimuli were arranged into 3 blocks separated by breaks. Each block contained 30 items, including 6 critical sentences ( 2 items per condition), 6 distractor sentences and 18 filler sentences. Stimuli were presented in courier font, size 18, on a black background using the Presentation software (Neurobehavioral Systems, Inc., Version 16.3 Build 12.20.12). Responses were recorded by key press on a Razer keyboard.

Stimuli sentences were displayed on the computer screen phrase-by-phrase (using a non-cumulative moving window paradigm). Each trial began with a series of dashes corresponding to the number of phrases displayed on the screen. Participants advanced through each sentence at their own pace by pressing the spacebar key. After each sentence, participants saw a comprehension question, to ensure that they were attending to the stimuli. Participants responded to the comprehension question by pressing either the left arrow or the right arrow button. Stimuli 
presentation was randomized across conditions, so that the same condition was not presented more than twice in a row, and by blocks. Before the actual experiment, participants read the instruction and were given 10 practice trials followed by explicit feedback.

\section{Experiment results}

Statistical analysis was carried out for each Interest Area, i.e. verb-region, NP2 (syntactic object) region, and spill-over region and was carried out with R 3.6.1 software (R Core Team 2019). Differences between mean reading times in the experimental conditions were analyzed using the Generalized Linear Mixed-Effects Model approach, using the lmer function from the lme4 package (Bates et al. 2015). In each Interest Area, the final model included experimental conditions as the fixed effect, whereas participants and stimuli were set as random intercepts. Response variable, i.e. reading times, was transformed using Box-Cox power transformation (using the powerTransform function from car package version 3.0-3; Fox and Weisberg 2019) to meet normal distribution of model residuals. Outliers were removed on the basis of their residual values. The significance of the main effect was estimated with loglikelihood on model comparison. For the main effect of the verb (agentive verb vs. eventive OE psych verb) a model with the intercept only was compared to a model with the fixed effect for experimental conditions. Model comparison produced statistically significant results in: (i) verb Interest Area $\left(\chi^{2}(5)=11.479 ; p=0.04267\right)$ and (ii) NP2 (syntactic object) Interest Area $\left(\chi^{2}(5)=12.143 ; p=0.03288\right)$. No significant result for the main effect was discovered in the spill-over Interest Area $\left(\chi^{2}(5)=7.8135 ; \mathrm{p}=0.1668\right)$.

\section{Comparison 1: labile OE psych-verbs in intentional contexts compared to labile OE psych-verbs in non-intentional contexts}

In the first Interest Area, i.e. on the verb region, we found a statistically significant difference between mean RTs for clauses with labile OE psych-verb in contexts eliciting intentional reading and clauses eliciting non-intentional reading $(\beta=-0.00217 ; \mathrm{t}(107.5)=-2.189 ; \mathrm{p}=0.0308)$. Labile OE psych-verbs in contexts eliciting non-agentive readings are processed faster than in clauses in which the intentional context is enforced.

In the NP2 (syntactic object) Interest Area, in contrast to the verb Interest Area, we did not find a statistically significant difference between mean RTs for clauses with labile $\mathrm{OE}$ psych-verbs in contexts eliciting intentional reading and clauses eliciting non-intentional reading $(\beta=0.00009 ; \mathrm{t}(1582)=0.612 ; \mathrm{p}=0.54077)$.

The results obtained for Comparison 1 support our assumption regarding the processing differences of labile OE psych-verbs in intentional and non-intentional readings. 


\section{Comparison 2: agentive verbs in intentional contexts compared to labile $\mathrm{OE}$ psych-verbs in intentional contexts}

In the first Interest Area, i.e. on the verb region, we did not find a statistically significant difference between mean RTs for clauses with agentive verbs and clauses with labile OE psych-verbs $(\beta=0.0005 ; \mathrm{t}(106.7)=0.505 ; \mathrm{p}=0.6147)$.

In the NP2 (syntactic object) Interest Area, we found a statistically significant difference between agentive and labile OE psych-verbs in clauses which elicited intentional reading $(\beta=-0.0004 ; \mathrm{t}(1582)=-2.986 ; \mathrm{p}=0.00287)$. Labile OE psychverbs are processed faster by parsers in this region.

The results obtained for Comparison 2 falsify our assumption regarding the lack of processing differences between labile OE psych-verbs and canonical agentive verbs. The results of the analysis for the comparisons presented in this study are summarized below in Table 2. Descriptive statistics for the planned comparisons conditions are provided in Table 3.

Table 2: Summary of experiment results. Statistically significant differences are marked in grey

\begin{tabular}{|l|l|l|}
\hline $\begin{array}{c}\text { Interest } \\
\text { Area }\end{array}$ & \multicolumn{1}{|c|}{ Comparison 1 } & \multicolumn{1}{c|}{ Comparison 2 } \\
\hline & $\begin{array}{l}\text { intentional contexts vs. non-intentional } \\
\text { contexts with respect to labile OE psych- } \\
\text { verbs }\end{array}$ & $\begin{array}{l}\text { agentive verbs vs. labile OE psych-verbs } \\
\text { in intentional contexts }\end{array}$ \\
\hline Verb IA & $\begin{array}{l}\text { statistically significant difference: } \\
\text { intentional contexts exhibit longer RTs }\end{array}$ & no statistically significant differences \\
\hline NP2 IA & no statistically significant differences & $\begin{array}{l}\text { statistically significant difference: } \\
\text { eventive OE psych-verbs exhibit shorter } \\
\text { RT }\end{array}$ \\
\hline
\end{tabular}

Table 3: Descriptive statistics for the conditions used in planned comparisons. meanRT is the mean reading time after Box-Cox power transformation was applied

\begin{tabular}{|c|l|c|c|c|c|c|}
\hline IA & \multicolumn{1}{|c|}{ Condition } & $\mathrm{N}$ & meanRT & sd & se & ci \\
\hline verb & agentive_intentional & 260 & 0.1326211 & 0.01627574 & 0.001009379 & 0.001987634 \\
\hline verb & OE_intentional & 264 & 0.1336373 & 0.01598153 & 0.000983595 & 0.001936723 \\
\hline verb & OE_non-intentional & 257 & 0.1317193 & 0.01583821 & 0.00098796 & 0.001945564 \\
\hline & & & & & & \\
\hline NP2 & agentive_intentional & 270 & 0.00880016 & 0.002847532 & 0.000173295 & 0.000341188 \\
\hline NP2 & OE_intentional & 271 & 0.00836767 & 0.002805624 & 0.00017043 & 0.00033554 \\
\hline NP2 & OE_non-intentional & 267 & 0.00843701 & 0.002709584 & 0.000165824 & 0.000326494 \\
\hline
\end{tabular}




\section{Discussion}

As presented above, the results of the experiment presented in this article point to the existence of differences within the class of labile OE psych-verbs and between labile OE psych-verbs and canonical agentive verbs. However, these differences appear to be of different nature (verb-related and NP-related) as they are elicited in different regions of the clauses. Therefore, below, they are accounted for in terms of distinct underlying causes.

\section{Comparison 1: the difference between intentional and non-intentional read- ings of labile $\mathrm{OE}$ psych-verbs}

With respect to the processing differences between intentional and non-intentional readings of clauses built around labile OE psych-verbs, the results of the presented experiment showed that non-intentional readings are parsed significantly faster than intentional ones. This difference becomes psychologically visible once the comprehenders encounter the verb that is to be integrated with the subject NP and the adverb. Accordingly, the integration of the verb in clauses in which the non-intentional reading is enforced and the subject NP is analyzed as the CAUSE is less taxing than a parallel operation in clauses in which the AGENT interpretation of the subject NP is enforced, i.e. in intentional contexts. The processing differences visible in Comparison 1 are elicited already at the verb, and are not present at other clause regions, which suggests that the distinction between intentionality (agentivity) and non-intentionality (eventivity) of an OE psych-verb is a property of the verb itself and is not influenced by the remaining clause material. Therefore, it can be argued that the obtained results indicate a presence of the structural difference in the make-up of $v \mathrm{P} / \mathrm{VP}$ in the two readings under investigation.

The observed processing difference between intentional and non-intentional readings can be straightforwardly accounted for by resorting to the structural composition of vP/VP proposed by Ramchand (2008) and Rozwadowska (in press), who modifies the Ramchandian structure to provide a more adequate structure of $\mathrm{vP} / \mathrm{VP}$ hosting $\mathrm{OE}$ verbs. Under this perspective, $\mathrm{vP} / \mathrm{VP}$ is a complex structure consisting of maximally three verbal projections, each of which introduces a separate subevent component. Each projection hosts a specifier position into which an argument selected by the verb can be merged. Merging of an argument can be external or internal-from a lower specifier position.

In the case of non-intentional readings of labile OE psych-verbs, the vP/VP is argued to consist of Initiation and State layers, see Rozwadowska (in press). Such a structure of $\mathrm{vP} / \mathrm{VP}$ is a modified version of Ramchand's Initiation-Process-Result configuration, and Fábregas and Marín's (in press) Initiation-Result structure. The $\mathrm{vP} / \mathrm{VP}$ structure argued for by Rozwadowska (in press) is presented in (10b). Its adaptation to account for the non-intentional readings of labile OE psych-verbs is presented schematically in (11). 
(10) a. Fábregas and Marín (in press):

[InitP [[Init ] [ResP [DP2] [[Res ROOT] [DP1]]]]]

b. Rozwadowska (in press):

[InitP [[Init ] [StateP [DP2] [[State ROOT] [DP1]]]]]

(11) Non-intentional reading 6

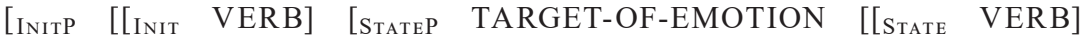
[EXPERIENCER]]]]]

As presented in (11), in non-intentional readings of labile OE psych-verbs the INIT(iation)P(hrase) lacks a specifier position into which a volitional instigator (or causer of emotion (CoE) in Fábregas and Marín's terminology) could be externally or internally merged. Fábregas and Marín need their structure presented here in (10) but containing ResP (Result Phrase) instead of StateP to account for one of the subgroups of Spanish psych verbs, which lack both the eventive component and the initiator. In (10), the INITP layer is defective (Schäfer 2008) and does not introduce its own specifier, because there is no causer of emotion - the subject is assigned the interpretation of the target of emotion (ToE). This structure is postulated to avoid the interpretation of the causer of the emotion. ToE is introduced lower (within RESP in their structure) as the entity towards which the mental state of the experiencer expressed by the root is directed. Rozwadowska (in press) argues that psych eventualities have neither a causer nor a process subevent leading to the result state; therefore, RESP postulated by Fábregas and Marín (in press), implying telicity, must be replaced with the STATEP.

With respect to intentional readings of labile OE psych-verbs, the structure of $\mathrm{vP} / \mathrm{VP}$ proposed by Ramchand (2008) is assumed. Accordingly, as is presented in (12), the vP/VP contains Initiation, Process and Result layers. The adaption of Ramchand's structure without any modifications in those cases is motivated by the fact that the processing of clauses with canonical agentive verbs and labile OE psychverbs does not differ at the verb region (see section 4, Comparison 2) and, anticipating the discussion on Comparison 2, the difference between these two types of clauses relates to the properties of the referent of EXPERIENCER and THEME.

(12) Intentional reading

[InitP AGENT [[Init VERB] [ProcP AGENT [[Proc VERB] [ResP RESULTEE

$[[\operatorname{Res} V E R B][X P]]]]]]]$

${ }^{6}$ In contrast to our approach, Alexiadou and Anagnostopoulou (2019) argue that the difference between agentive and non-agentive readings of OE psych-verbs is centred on the presence / absence of the Voice layer in the vP structure. What is more, even if the Voice layer is missing, as is the case in non-agentive readings, the trigger of the mental states is treated by Alexiadou and Anagnostopoulou (2019) as a CAUSER. In our approach we argue that in non-agentive readings the CAUSER as such is entirely missing, to ensure that the trigger of the mental state is interpreted solely as the TARGET-OF-EMOTION. We find this approach more descriptively adequate as far as the cognition of non-agentive OE psych-verbs is concerned. 
As presented in (12), in intentional readings the argument of the verb which is understood as AGENT ('volitional agent' in Ramchand's terms) is first externally merged in the SpecProcP slot, where it is being assigned the UNGERGOER role which encodes the fact that the AGENT-argument is understood here as participating in the process by controlling it. This merger reflects the fact that AGENT is understood as being continuously involved in the psychological process denoted by the verb by controlling the process itself. For instance in a clause such as John was intentionally irritating Mary, John is understood as wilfully performing actions that irritate Mary, i.e. John is consciously controlling the process of irritating Mary. Next, the AGENT argument is internally merged from the SpecProcP to SpecInitP slot, in (12). Internal merging into the SpecInitP position encodes the AGENT argument as the instigator of the event denoted by the verb. As a result, the AGENT argument is associated with two specifier positions and two functions in the structure of the $\mathrm{vP} / \mathrm{VP}$, i.e. it receives a composite Initiator-Undergoer role.

Given the compositions of $\mathrm{vP} / \mathrm{VPs}$ presented in (11) and (12), the differences in mean reading times between intentional and non-intentional readings of clauses with labile OE psych-verbs can be easily accounted for. Non-intentional readings, which exhibit shorter reading times, have a less complex event structure consisting of mental state experience linked with the object with respect to which this state is oriented (reflected by phrase marker in (11)), whereas intentional readings, whose event structure involves the process subevent which leads to a result state subevent, are associated with a more complex structure. This increased complexity of event in intentional readings is reflected in a greater processing burden.

\section{Comparison 2: the difference between labile OE psych-verbs and canonical agentive verbs in intentional reading eliciting contexts}

Results of the presented experimental study indicate that labile OE psych-verbs when used in intentional readings do not differ from canonical agentive verbs as far as the processing of the verb itself is concerned. The observed difference is not visible on the verb but is elicited on the syntactic object, which suggests that it is the semantic properties of the Internal Arguments, not the verbs themselves, which underlie the processing differences. Therefore, it will be argued that these two classes of verbs differ only with respect to the processing of the Internal Argument. In these cases, the internal arguments of the canonical agentive verbs create more processing burden, i.e. the integration of the THEME argument with the verb inside the VP is more costly than the integration of the EXPERIENCER argument.

In order to account for the above, Animacy and Thematic Hierarchies (see Whaley 1997; Jackendoff 1972; Belletti and Rizzi 1988; or van Gelderen 2018, among others) may be applied. ${ }^{7}$ These hierarchies are illustrated in (13) and (14), respectively.

7 The exploitation of the Animacy and Thematic Hierarchies to account for the observed differences in Comparison 2 is also in line with the theoretical apparatus employed in accounting for 
(13) Animacy Hierarchy

1st and 2 nd person $>3$ rd person pronoun $>$ proper name/kin term $>$ human noun, animate noun, inanimate noun

(14) Thematic Hierarchy

Agent $>$ Causer $>$ Experiencer $>$ Theme $>$ Goal

Both hierarchies have been applied to account cross-linguistically for mapping the arguments selected by the verbs, overtly realized as NPs, into the syntactic subject and object positions. The relative order of properties on the hierarchies reflects the preference for an NP, built around the noun carrying a relevant semantic property, to be realized as occupying the highest available nominal position in the hierarchical structure of the phrase marker. What is more, van Gelderen (2018), based on the body of previous research into the relationship between animacy and thematic role assignment, notes that Animacy Hierarchy and Thematic Hierarchy appear to be mutually complementing each other. Namely, she notes that the arguments higher on the thematic tier are typically realized more often by nouns with animate referents than the lower arguments, such as the THEME, which are more typically associated with inanimate referents.

As for Comparison 2, in both clause types (with labile OE psych-verbs and canonical agentive verbs) we assume the event structure in (12). EXPERIENCER and THEME arguments are integrated in the SpecResP position. Given that in both conditions noun referents do not differ with respect to Animacy Hierarchy, i.e. both are human referring nouns, it seems that the locus of the difference is the preference for realizing the syntactic object as a human referring EXPERIENCER in contrast to a human referring THEME. The association of EXPERIENCER with a human referring noun was shown to be linguistically relevant by Levin and Grafmiller (2013), who focused on the referential properties of the EXPERIENCER and CAUSE arguments with respect to fear and frighten in English. The results of their corpus study show that in the case of frighten, the EXPERIENCER argument is realized by a human referring NP in $33.3 \%$ of the cases in their sample of 330 clauses, whereas the use of other NP types is distributed as follows: $26.4 \%$ (abstract entity), 16.1\% (concrete object), 14.8\%, (event), 5.5\% (proposition) and 3.95 (animate, non-human).

Therefore, since the realization of the EXPERIENCER by human referring NP is more plausible than that of the THEME, the difference in the processing of clauses with eventive OE psych-verbs with respect to clauses with canonical agentive verbs can be argued to reflect the match (in the case of EXPERIENCERS) and mismatch (in the case of THEMES) between the animacy of the referent of the IA and parsers' linguistic knowledge. Accordingly, the integration of the verb with

Comparison 1. With respect to Comparison 1, the focus was placed on the structural differences in $\mathrm{vP} / \mathrm{VP}$. As for Comparison 2, the focus is shifted to what Ramchand (55) terms 'referential properties of the DP participant'. 
an animate EXPERIENCER is less taxing than its integration with an animate THEME, the latter more likely to be associated with inanimate referents.

\section{Conclusions}

The aim of the presented research was to investigate the processing of Polish labile OE psych-verbs in clauses eliciting intentional and non-intentional readings and to compare processing of labile $\mathrm{OE}$ psych-verbs in intentional contexts to processing of canonical agentive verbs. The results of the conducted self-paced reading experiment showed that processing of labile OE psych-verbs differs with respect to (i) the elicited context (intentional vs. non-intentional), and (ii) the difference between labile $\mathrm{OE}$ verbs and canonical agentive verbs in intentional contexts.

The differences with respect to the elicited context indicate that labile OE psych-verbs are more easily parsed in non-intentional contexts, with the difference occurring already at the verb region. This observation was accounted for in terms of distinct structures of $\mathrm{vP} / \mathrm{VP}$ underlying the non-intentional and intentional readings. The non-intentional readings exhibit significantly shorter reading times and are argued to be associated with an event structure that lacks the process subevent. This result extends Verhoeven's (2010) and Darby's (2016) approaches, which support distinct treatment of OE psych-verbs in their intentional (agentive) and unintentional (non-agentive) uses.

As for the processing differences between labile OE psych-verbs and canonical agentive verbs, the conducted experiment showed a significant difference at the Internal Argument region (the syntactic object position). As presented, clauses with labile OE psych-verbs, which host the EXPERIENCER, are processed faster. This processing difference is argued to stem from a greater association of a human referring NP with the EXPERIENCER than with the THEME. On the whole, these results indicate that the difference between labile OE psych-verbs and canonical agentive verbs does not lie in the verbs themselves but results from distinct semantic associations of their arguments. In other words, our results are compatible with the constructivist theories to the lexicon-syntax interface. At the same time, the results reported here do not contradict the results obtained by Verhoeven (2010), Grafmiller (2013) and Darby (2016), as in those studies respective measures were taken for entire clauses. Instead, our study sheds more light on the complex nature of the syntax-semantics mapping in clauses with eventive OE psychverbs. Finally, the present study provides support for the distinct nature of psych verbs as compared to canonical agentive verbs, an issue which has been a matter of unsettled debate for a few decades, and still remains controversial. It has been shown here that on non-agentive reading $\mathrm{OE}$ verbs have a simpler event structure and are processed quicker. Only when there are appropriate contextual triggers do they acquire agentive properties. 


\section{Acknowledgements}

This research was funded by grant 2014/15/B/HS2/00588 from the National Science Centre, Poland.

We are grateful to two anonymous reviewers for their insightful and inspiring comments that open new directions for further research.

\section{References}

Arad, M. 1998. "Psych-notes." UCL Working Papers in Linguistics 10. London: U College.

Alexiadou, A. and A. Anagnostopoulou. 2019. "Novel Experiencer-Object Verbs and Clitic Doubling." Syntax 22(2). 116-45.

Alexiadou, A. and G. Iordachioaia. 2014. "The psych causative alternation." Lingua 148. 53-79.

Bates, D., M. Mächler, B. Bolker and S. Walker. 2015. "Fitting Linear Mixed-Effects Models Using lme4." Journal of Statistical Software 67(1). 1-48.

Belletti, A. and L. Rizzi. 1988. "Psych-verbs and theta-theory." Natural Language and Linguistic Theory 6.3. 291-352.

Bornkessel-Schlesewsky, I., F. Kretzschmar, S. Tune, L. Wang, S. Genç, M. Phillipp et al. 2011. "Think globally: Cross-linguistic variation in electrophysiological activity during sentence comprehension." Brain and Language 117(3). 133-52.

Bourguignon, N., J. E. Drury, D. Valois and K. Steinhauer. 2012. "Decomposing animacy reversals between agents and experiencers: An ERP study." Brain and Language 122. 179-89.

Darby, J. 2016. "Assessing agentivity and eventivity in object-experiencer verbs: the role of processing." Conference presentation. 38th Conference of the DGfS. Berlin, 26 Feb. 2016.

Fábregas, A. and R. Maŕin (in press). "Initiators, states and passives in Spanish psych verbs." In: Rozwadowska, B. and A. Bondaruk (eds.). Beyond emotions in language. Psychological verbs at the interfaces. Amsterdam/Philadelphia: John Benjamins, 113-140.

Fox, J. and S. Weisberg. 2019. An R Companion to Applied Regression. Thousand Oaks, CA: Sage. Grafmiller, J. 2013. "The Semantics of Syntactic Choice. An Analysis of English Emotion Verbs". PhD Diss. Stanford University.

Grimshaw, J. 1990. Argument structure. Cambridge, MA: MIT P.

Jackendoff, R. 1972. Semantic Interpretation in Generative Grammar. Cambridge, MA: MIT P.

Keating, G. and J. Jegerski. 2015. "Experimental designs in sentence processing research.” Studies in Second Language Acquisition 37(1). 1-32.

Kilmek-Jankowska, D., A. Czypionka, W. Witkowski and J. Błaszczak. 2018. "The time course of processing perfective and imperfective aspect in Polish. Evidence from self-paced reading and eye-tracking experiments." Acta Linguistica Academica 65.2-3. 93-351.

Kuperberg, G. R. 2007. "Neural mechanisms of language comprehension: Challenges to syntax." Brain Research 1146. 23-49.

Landau, I. 2009. The locative syntax of experiencers. Cambridge, MA: MIT P.

Levin, B. and J. Grafmiller. 2013. "Do You Always Fear What Frightens You?" In: Holloway, T. and V. de Paiva (eds.). From Quirky Case to Representing Space: Papers in Honor of Annie Zaenen. Stanford, California: CSLI Publications, 21-32.

Pesetsky, D. 1995. Zero syntax: Experiencers and cascades. Cambridge, MA: MIT P.

Przepiórkowski A., M. Bańko, R. Górski and B. Lewandowska-Tomaszczyk. 2012. Narodowy Korpus Języka Polskiego. Warszawa: Wydawnictwo PWN.

Ramchand, G. 2008. Verb Meaning and the Lexicon: A First Phase Syntax. Cambridge: Cambridge UP. 
R Core Team. 2019. $R$ : A language and environment for statistical computing. $R$ Foundation for Statistical Computing. Vienna, Austria. Retrieved from http://www.R-project.org. 5 May 2019.

Rozwadowska, B. (in press). "Polish psych-verbs as non-achievements." In: Rozwadowska, B. and A. Bondaruk (eds.). Beyond emotions in language. Psychological verbs at the interfaces. Amsterdam-Philadelphia: John Benjamins.

Sonnenhauser, B. 2010. "The event structure of verbs of emotion in Russian." Russian Linguistics 34. 331-53.

Van Gelderen, E. 2018. The Diachrony of Verb Meaning. Aspect and Argument Structure. New York: Routledge.

Van Valin, R. D. Jr. and D. P. Wilkins. 1996. "The case for 'effector': case roles, agents, and agency revisited.” In: Shibatani, M. and S. A. Thompson (eds.). Grammatical constructions: their form and meaning. Oxford: Clarendon, 289-322.

Verhoeven, E. 2010. "Agentivity and stativity in experiencer verbs: Implications for a typology of verb classes." Linguistic Typology 14.2-3. 213-52.

Whaley, L. 1997. An Introduction to Language Typology. Thousand Oaks, CA: Sage. 